Vol. 28 No. 4, 2016

DOI:https://doi.org/10.26725/JEE.2016.4.28.5760-5763

\title{
Scenario Analysis of Rice Cultivation in Kerala
}

\section{H. Athira ${ }^{1}$ and N. Kishore Kumar ${ }^{2}$}

\begin{abstract}
Rice is the staple food crop of Kerala. At present only $12 \%$ of the gross cropped area in the state is under paddy. The paddy fields in Kerala are constantly getting converted for other purposes. A steady decline in the area under rice cultivation occurred from 1980 s onwards. This paper studies the changing trend in rice cultivation and provides the factors leading to shifting of rice cultivation.
\end{abstract}

Keywords : Rice, scenario analysis, Kerala.

Rice is the second largest cereal produced and consumed in the world. India occupies second position in terms of its production. India is one of the world's largest producer of white rice and brown rice, accounting for $20 \%$ of global rice production.

Kerala, a constituent state of India has a rich history and tradition of rice cultivation. The very first thing that comes to our mind when we say Kerala, is her green cover and paddy fields. But today the situation is different. Paddy fields in Kerala are fast disappearing.

Lush green fields which once invoked prosperity and growth are now invaded by concrete buildings and sky touching malls showing a way to an uncertain future.

The Palakkad district, which is considered the rice bowl of Kerala, has lost $1,03,980$ hectares of paddy fields in the last four decades. Even though the food habits of the people of Kerala had remarkably changed over the last few decades, rice still continues to be their staple food. The decline in paddy cultivation and large-scale reclamation of traditional rice fields have started to adversely affect groundwater availability in the state. Paddy fields can regulate atmospheric temperature to some extent. Studies attribute the increasing day time temperature in Palakkad district as a consequence of large-scale reclamation of paddy fields.

Over the last ten years, however, there has been a commendable sign of revival in rice production in Kerala. The average productivity rose from $2.21 \mathrm{t} / \mathrm{ha}$ in 2002-03 to $2.87 \mathrm{t}$ / ha by the year 2015 .

This paper studies the changing trend in rice cultivation over the years and also reports the factors leading to shifting

1. PG Scholar and 2. Professor, Department of Agricultural Extension, College of Agriculture, Kerala Agricultural University, Vellayani-695 522

Received : 28-03-2017; Accepted : 13-04-2017 
of rice cultivation. It also attempts to find out various constraints faced by farmers.

\section{METHODOLOGY}

The primary data for the study were collected from paddy farmers of Palakkad district of Kerala. Four blocks were purposively selected for this study. Palakkad district was selected because it occupies the first position in the production of rice in the state. According to the latest estimates, paddy is cultivated in around 83,998 hectares in the district. The secondary data for the study were collected from journals, publications by various academic organizations, research studies, and the data published in the official website of Economics and Statistics Department of Kerala.

\section{FINDINGS AND DISCUSSION Changing Trend in Rice Cultivation over the Years}

The area under paddy cultivation increased considerably during the first fifteen years after the State's formation - from 7, 60,000 hectares in 1955-56 to $8,80,000$ hectares in 1970-71. In 196566 , rice accounted for the highest share of gross cropped area in Kerala (32 per cent of the total). There was, however, a steady decline in the area under rice cultivation from the 1980s onwards from 8, 50,000 hectares in 1980-81 to $5,60,000$ hectares in 1990-91, and to 2,30,000 hectares in 2007-08 (Thomas, 2011). Presently rice is cultivated in an area of 1.98 lakh ha with a production of 5.62 lakh tonnes (GoK, 2017). Today, rice occupies only the third position among Kerala's agricultural crops with respect to area under cultivation, and unfortunately it is far behind coconut and rubber.

\section{Factors Leading to Shifting of Rice Cultivation}

It is often felt that seasonal shortage of agricultural labour is a major factor leading to shifting of rice cultivation in Kerala today. Movement of work force from agriculture to a diverse set of non-agricultural occupations has been occurring at a much faster rate in Kerala when compared to the rest of India from the early decades of the 20th century. The Mahatma Gandhi National Rural Employment Guarantee Scheme can be better utilized for resolving the labour shortage in agriculture (Thomas, 2011). Inadequate irrigation facilities is another reason for shifting trends in rice production. Productivity is found to be low in areas which lacks proper irrigation facilities. The factors perceived by the farmers for the declining trend in rice cultivation were ranked according to their importance and are presented in Table 1.

Interestingly, some farmers pointed out that they are willing to enhance their cultivation if adequate irrigation facilities are available. Wild animal menace is on the rise in the district . Crop damage by wild animals in agricultural fields adjacent to forest areas is severe. 
Table 1 .

Factors Leading to Shifting of Rice Cultivation

\begin{tabular}{|c|c|c|c|}
\hline $\begin{array}{l}\text { S1. } \\
\text { No. }\end{array}$ & Dimensions & Factors & Rank \\
\hline \multirow{6}{*}{1.} & \multirow{6}{*}{ Technological } & i) Competition from other crops & 3 \\
\hline & & $\begin{array}{l}\text { ii) Biotic stress caused due } \\
\text { to insect, disease, nematode, } \\
\text { rodent and weeds }\end{array}$ & 2 \\
\hline & & iii) Wild animal attacks & 1 \\
\hline & & $\begin{array}{l}\text { iv) Unavailability of timely } \\
\text { supply of inputs }\end{array}$ & 6 \\
\hline & & $\begin{array}{l}\text { v) Lack of accessibility to } \\
\text { mechanization }\end{array}$ & 5 \\
\hline & & vi) Unscientific storage facilities & 4 \\
\hline \multirow[t]{5}{*}{2.} & \multirow[t]{5}{*}{ Economical } & i) Less productivity & 3 \\
\hline & & ii) Low levels of profitability & 2 \\
\hline & & $\begin{array}{l}\text { iii) Procurement problems and } \\
\text { fluctuating prices }\end{array}$ & 1 \\
\hline & & iv) High cost of inputs & 4 \\
\hline & & v) Credit problems & 5 \\
\hline \multirow[t]{4}{*}{3.} & \multirow[t]{4}{*}{ Social / ecological } & $\begin{array}{l}\text { i) Seasonal shortage in labour } \\
\text { supply }\end{array}$ & 1 \\
\hline & & $\begin{array}{l}\text { ii) Forced to convert land for } \\
\text { building purpose }\end{array}$ & 3 \\
\hline & & $\begin{array}{l}\text { iii) Less support from family } \\
\text { members }\end{array}$ & 4 \\
\hline & & $\begin{array}{l}\text { iv) Uneven rainfall pattern and } \\
\text { climate change }\end{array}$ & 2 \\
\hline \multirow[t]{2}{*}{4.} & \multirow[t]{2}{*}{ Political } & $\begin{array}{l}\text { i) Changing Governments and } \\
\text { policies }\end{array}$ & 2 \\
\hline & & ii) Labour problems & 1 \\
\hline
\end{tabular}


This is primarily due to the straying of wild animals such as wild boar, Asian elephant, Indian porcupine and deer from the forest to the homesteads and plantations. Consequent to this, conflict between wild animals and farmers in the fringe areas of the forests and protected areas are rising. This might have influenced the farmers to convert paddy lands to rubber plantations.

Rice being the staple food crop of Keralites and as Kerala's population continues to grow steadily, demand for rice is also growing. The challenge before the Government for the next few years will be to feed the escalating population, keeping the prices low to benefit poor consumers and reducing production costs to benefit poor growers.

The gap between demand and supply of rice which was around fifty percent till the mid-seventies is widening every year as the area under rice declined at a very fast rate due to large scale conversion of paddy lands for raising other cash crops such as coconut, rubber, banana, etc. or for residential purposes. With the gap between production and requirement of food grain widening every year, Kerala's food scene is showing a blurred picture. As a wakeup call much of the additional food demand in the future will have to be met through productivity enhancement. The current productivity of $2.8 \mathrm{t} /$ ha must be improved. The study has revealed that labour shortage is one of the major problems in rice cultivation. Mechanization of agriculture operation may help to increase rice cultivation and curb the problems of labour shortage. Many had felt that the increase in the frequency of droughts and floods and also an increase in temperatures is likely to to have a negative impact on rice yields. Developing and promoting the spread of rice varieties that are less sensitive to such climatic changes is the one of the options for thriving such situations. Greater investment in research and extension is inevitable to meet these challenges.

\section{REFERENCES}

Directorate of Economics and Statistics, Kerala. (2015). Retrieved from http://www.ecostat.kerala. gov.in/index.php/component/ search / rice \% 20 production . html?ordering $=\&$ searchphrase $=$ all

GoK [Government of Kerala]. (2017). Farm Guide. Farm Information Bureau, Thiruvananthapuram, 320p.

Thomas, J. J. (2011). Paddy cultivation in Kerala. Electronic Journal of Agriculture Studies 2(1). Retrieved from http:// www.ras.org.in/paddy cultivation in kerala/content/ vol.2/issue 1 /index. html. 